CLINICAL STUDY

\title{
Prevalence of mutations in TSHR, GNAS, PRKAR1A and RAS genes in a large series of toxic thyroid adenomas from Galicia, an iodine-deficient area in NW Spain
}

\author{
F Palos-Paz ${ }^{1}$, O Perez-Guerra ${ }^{1}$, J Cameselle-Teijeiro ${ }^{3}, \mathrm{C}$ Rueda-Chimeno ${ }^{5}$, F Barreiro-Morandeira $^{4}$, J Lado-Abeal ${ }^{1,2}$ \\ and the Galician Group for the Study of Toxic Multinodular Goitre: D Araujo Vilar ${ }^{1,2}$, R Argueso ${ }^{7}, \mathrm{O}^{\text {Barca }}{ }^{1}$, \\ M Botana $^{7}$, J M Cabezas-Agrícola ${ }^{2}$, P Catalina ${ }^{6}$, L Dominguez Gerpe ${ }^{1}$, T Fernandez ${ }^{9}$, A Mato ${ }^{8}$, A Nuño ${ }^{11}$, M Penin ${ }^{10}$ \\ and B Victoria ${ }^{1}$ \\ ${ }^{1}$ Unidade de Enfermedades Tiroideas e Metabólicas (UETeM), ${ }^{2}$ Endocrinology Section, Department of Medicine, ${ }^{3}$ Pathology Department and ${ }^{4}$ Surgery \\ Department, Complexo Hospitalario Universitary de Santiago (CHUS), University of Santiago de Compostela, Santiago de Compostela, 15705, Spain, \\ ${ }^{5}$ General Surgery Section and ${ }^{6}$ Endocrinology Section, Complexo Hospitalario de Pontevedra, Pontevedra, Spain, ${ }^{7}$ Endocrinology Section, Complexo \\ Hospitalario Xeral-Calde, Lugo, Spain, ${ }^{8}$ Endocrinology Section, Complexo Hospitalario de Ourense, Ourense, Spain, ${ }^{9}$ Endocrinology Section, Complexo \\ Hospitalario Universitario Juan-Canalejo, A Coruña, Spain, ${ }^{10}$ Endocrinology Section, Hospital Arquitecto Marcide, Ferrol, Spain and ${ }^{11}$ General Surgery \\ Section, Hospital do Meixoeiro, Complexo Hospitalario Universitario de Vigo, Vigo, Spain \\ (Correspondence should be addressed to J Lado-Abeal who is now at UETeM, Department of Medicine, School of Medicine, University of Santiago de \\ Compostela, C/San Francisco sn 15705, Santiago de Compostela, Spain; Email: joaquin.lado@usc.es)
}

\begin{abstract}
Objective: Toxic thyroid adenoma (TA) is a common cause of hyperthyroidism. Mutations in the TSH receptor (TSHR) gene, and less frequently in the adenylate cyclase-stimulating G alpha protein (GNAS) gene, are well established causes of TA in Europe. However, genetic causes of TA remain unknown in a small percentage of cases. We report the first study to investigate mutations in TSHR, GNAS, protein kinase, cAMP-dependent, regulatory, type I alpha (PRKAR1A) and RAS genes, in a large series of TA from Galicia, an iodine-deficient region in NW Spain.

Design and methods: Eighty-five TA samples were obtained surgically from 77 hyperthyroid patients, operated on for treatment of non-autoimmune toxic nodular goitre. After DNA extraction, all coding exons of TSHR, GNAS and PRKAR1A genes, and exons 2 and 3 of HRAS, KRAS and NRAS were amplified by PCR and sequenced. Previously unreported mutants were cloned in expression vectors and their basal constitutive activities were determined by quantification of cAMP response element (CRE)-luciferase activity in CO7 cells transfected with wild-type and mutant plasmids.

Results: TSHR gene mutations were found in 52 (61.2\%) samples, GNAS gene mutations in 4 (4.71\%) samples and no PRKAR1A or RAS mutations were found. Only three previously unreported mutations were found, two affecting the TSHR, A623F and I635V, and one affecting the G-protein $\alpha$-subunit (Gs $\alpha$ ), L203P. All mutant proteins showed higher CRE-luciferase activity than their wild-type counterparts. Conclusions: TA in a hyperthyroid population living in Galicia, a Spanish iodine-deficient region, harbours elevated frequencies of TSHR and GNAS mutations activating the cAMP pathway. However, the genetic cause of TA was undetermined in $34 \%$ of the TA samples.
\end{abstract}

European Journal of Endocrinology 159 623-631

\section{Introduction}

Non-autoimmune toxic nodular goitre is a common cause of hyperthyroidism in iodine-deficient regions $(1$, $2)$. Although several epidemiological risk factors for nodular goitres are well characterized (3), the molecular basis for most non-autoimmune toxic nodular goitres remains unknown (2). An exception is toxic thyroid follicular adenoma (TA) that is caused by activating mutations in the thyroid-stimulating hormone receptor (TSHR) gene (4) or, less frequently, in adenylate cyclasestimulating G $\alpha$-protein (GNAS) gene (5). In the absence of ligand binding, these mutations activate the TSHR and the stimulatory Gs $\alpha$, increasing intracellular cAMP levels and thus stimulating thyrocyte proliferation and thyroid hormone secretion (6). TSHR stimulation also activates the phospholipase C-diacylglycerol-inositol phosphate cascade (6), although the effects of this pathway in the pathogenesis of TA remain unknown (7).

Cyclic-AMP-dependent protein kinase (PKA) mediates the majority of effects of cAMP in many cell types and is required for the mitogenic stimulation of thyrocytes by thyroid-stimulating hormone (TSH) (8). Inactive PKA consists of a tetramer of two regulatory and two catalytic subunits. Binding of cAMP to the regulatory 
subunits causes dissociation of the inactive enzyme into a dimer of regulatory protein bound to cAMP and two free catalytic subunits that phosphorylate specific substrates. PRKAR1A, the gene that codes for the PKA regulatory-subunit type-I $\alpha(\mathrm{RI} \alpha)$, is mutated in Carney complex type 1, a lentiginosis syndrome with multiple neoplasia that affects the thyroid gland, causing a spectrum of abnormalities from follicular hyperplasia to carcinoma (9). To date, however, mutations in PRKAR1A have not been implicated in toxic nodular goitres.

The RAS gene family (HRAS, KRAS and NRAS) encodes membrane-associated guanosine nucleotidebinding proteins that play a role in the transduction of signals arising from tyrosine kinase and G-proteincoupled receptors. Point mutations affecting the GTPbinding domain (codons 12 and 13) and the GTPase domain (codon 61) result in constitutive activation of the protein and tumour development (10). RAS mutations have occasionally been described in TA, suggesting a possible role in its pathogenesis (11).

The reported prevalence of mutations in the TSHR and GNAS genes in TA approaches $80 \%$ in some iodinedeficient regions in Europe (2). Toxic multinodular goitre is common in several regions of Spain where iodine deficiency is still found, but as yet the molecular basis of toxic nodular goitre in Spain does not appear to have been investigated. Our objective was to study the prevalence of mutations in TSHR, GNAS, PRKAR1A and RAS genes in a large series of TA from patients living in Galicia, an iodinedeficient region located in NW Spain (12).

\section{Materials and methods}

\section{Thyroid tissue samples}

Eighty-five thyroid samples, obtained from surgical specimens from 77 Galician native patients (19 males and 58 females) between January 2004 and December 2007, were studied. Surgery was indicated due to long-standing non-autoimmune toxic nodular goitre. Patient age (mean \pm s.D.) was $53.6 \pm 15.4$ years (range: $22-78$ years). Patients were from six hospitals of the Servicio Galego de Saude (SERGAS), the public healthcare network of Galicia. Three hospitals were University affiliated and three were first level hospitals without academic affiliation. All patients underwent a blood thyroid hormone test with serum TSH, free thyroxine $\left(\mathrm{FT}_{4}\right)$, free triiodothyronine $\left(\mathrm{FT}_{3}\right)$ and thyroid autoantibodies (TPOAb, TGAb) measured, a thyroid ultrasonography and a thyroid technetium $99 \mathrm{~m}\left({ }^{99 \mathrm{~m}} \mathrm{Tc}\right)$ scan. Patients were clinically diagnosed with clinical or subclinical hyperthyroidism, caused either by a non-autoimmune toxic solitary nodule or by a multinodular goitre, and referred for surgery. Pathological analysis revealed at least one TA in each surgical specimen. Care was taken to confirm that the location of each adenoma in the thyroid specimen corresponded to a previously detected 'hot' area from the ${ }^{99 \mathrm{~m}} \mathrm{Tc}$ scan. Tissue samples were taken from within the TA, from fresh (71 samples) or paraffin-embedded specimens (14 samples). The study was approved by the Ethics Review Panels of the Consellería de Sanidade (Xunta de Galicia, Spain) and the University of Santiago de Compostela.

\section{Genetic studies}

DNA samples were extracted using REALPURE Extraction DNA kit (Durviz, Valencia, Spain). Paraffinembedded thyroid tissue was deparaffinated in xylene and a graded series of ethanol prior to DNA extraction. Out of 21 samples, 7 embedded in paraffin were rejected because of non-adequate DNA for PCR amplification.

TSHR gene coding exons and exons 2 and 3 of HRAS, KRAS and NRAS genes were directly sequenced in the 85 TA tissue samples. In samples that were found to have no mutations in TSHR and RAS (28 nodules), GNAS coding exons were sequenced completely and, in samples that had no mutations in TSHR, RAS or GNAS genes (24 nodules), PKAR1A exons 2-11 were sequenced. Exons and adjacent intron fragments of $50-100 \mathrm{bp}$ were amplified by PCR (Tables 1 and 2 show oligonucleotide sequences; PCR conditions are available on request) and sequenced in an ABI PRISM 3100 (Applied Biosystems, Foster City, CA, USA) capillary electrophoresis apparatus. Where necessary, mutations were confirmed by enzyme restriction analysis or by fragment cloning into a pGEM-T TA cloning vector (Promega) followed by direct sequencing.

\section{Clonality (AR) assay}

Clonal origins of the TA tissues were analyzed by an $\mathrm{X}$-chromosome inactivation assay performed on the human androgen receptor gene, $A R$, as described by Allen et al. with minimal modifications (13). DNA (100 ng) per sample were digested for $16 \mathrm{~h}$ at $37^{\circ} \mathrm{C}$ in $20 \mu \mathrm{l}$ reactions with the methylation-sensitive HhaI (10 U) and HpaII (100 U) restriction enzymes (New England Biolabs, Hertfordshire, UK). Digestion efficacy was checked in parallel with a positive control DNA. A PCR $(50 \mu \mathrm{l})$ to amplify the polymorphic region inside $A R$ exon 1 was performed with $20 \mathrm{ng}$ digested DNA (PCR conditions and oligonucleotide sequences available on request). PCR products were loaded into a capillary electrophoresis apparatus (ABI PRISM 3100, Applied Biosystems) to separate each allele by fragment size. GeneScan - 500 LIZ Size Standard (Applied Biosystems) was included as an internal standard for the size fragment analysis. Allele intensity was calculated as described by Kopp et al. (14). A corrected ratio ((digested allele 1/allele 2)/(non-digested allele 1/allele 2)) value equal to or higher than three was chosen as the cut-off value for clonality, indicating that one of the 
Table 1 Oligonucleotide sequences for PCR amplification of TSHR and GNAS coding exons.

\begin{tabular}{|c|c|c|}
\hline Exon & Forward oligonucleotide & Reverse oligonucleotide \\
\hline \multicolumn{3}{|l|}{ TSHR } \\
\hline 10 & $\begin{array}{l}5^{\prime} \text {-GTCATGAGCCACTGCGCC-3' } \\
5^{\prime} \text {-CCCAGGAAGAGACTCTACAAGCT-3' } \\
5^{\prime} \text {-CCATCGACTGGCAGACAGG-3' } \\
5^{\prime} \text {-ACATAGTTGCCTTCGTCATCGT-3' } \\
5^{\prime} \text {-GCCTTCCAGAGGGATGTGTTC-3'3 }\end{array}$ & $\begin{array}{l}\text { 5'-GGTTGAACTCATCGGACTTGG-3' } \\
5^{\prime}-\text {-GAAACCAGCCGTGTTGCAC-3' } \\
5^{\prime} \text {-CGGATTTCGGACTGTGATGT-3' } \\
5^{\prime} \text {-GCTGTTCTTTGGAGGAACCC-3' } \\
5^{\prime} \text {-CCATGAAACATTGAAACATCGC-3' }\end{array}$ \\
\hline 9 & 5'-САTСTCCCAATTAACCTCAGGC-3' & $5^{\prime}$-CAAACCAGGAAGCATCTTCCC- $3^{\prime}$ \\
\hline 8 & 5'-AGCCCCTTGGAGCCCTC-3' & 5'-CTGCTTTTGTGCACTTCG GG-3' \\
\hline 7 & 5'-CCAACATATTGTGAAAACTGTCA-3' & 5'-AATATAACTGCCATTGATTTATGC-3' \\
\hline 6 & 5'-TCCATGAGGGTTGTACATGTT-3' & 5'-CAATCAAGAAACCAGCTCCC-3' \\
\hline 5 & 5'-GGTACCCTGTGGCGTAAATG-3' & 5'-CCTGGACCACATCATCTAGG-3' \\
\hline 4 & 5'-TTAGGGAAGGTGTTGGGAG-3' & 5'-TTATCTTCAACСТАСССТСАТGA-3' \\
\hline 3 & 5'-GCGGTTAAGAAGGGTCAGTG-3' & 5'-TGGATGGTCTGTAAACATATGAAA A-3' \\
\hline 2 & 5'-TGGGACCTGAAAAACCTT TATG-3' & 5'-TCTGGCGTGGAAGATGCT-3' \\
\hline 1 & 5'-GGGACTTGCAGAAGCCTT TAC-3' & 5'-GTGCTCAAGCCAGAAGAAGATA-3' \\
\hline \multicolumn{3}{|l|}{ GNAS } \\
\hline 1 & 5'-ATGGGCTGCCTCGGGAACAG-3' & $5^{\prime}$-TTACCCAGCAGCAGCAGGCCA-3' \\
\hline 2 & 5'-AAAATGCCTCСТTCATAACCTGA-3' & 5'-GCCCACCTATACTTCCTAAAG-3' \\
\hline 3 & 5'-ATGGTTGAGGAATGTAGAGAGACTG-3' & 5'-CAGTATGATCTTCATGTTTGTTTTG-3' \\
\hline $4-5$ & 5'-ATGAAAGCAGTACTCCTAACTGA-3' & 5'-TGGATGCTCCTGCCCATGTG-3' \\
\hline 6 & 5'-ATTAGTTCAAGCTCTTGCCTTTC- $3^{\prime}$ & 5'-TTGTCTGTTTTATGTGCTGATGG-3' \\
\hline 7 & 5'-TGCTGCATAACTGTGGGACG-3' & 5'-GTAGTTTGGAAAGAGGGCTCAG-3' \\
\hline $8-9$ & $5^{\prime}$-СCTCCCCACCAGAGGACTCTGAGCC-3' & 5'-AGAGCGTGCGCAGCGACCCTGCTC-3' \\
\hline 10 & 5'-TGTTAGGGATCAGGGTCGCTG-3' & 5'-AACAGTGCAGACCAGGGCCTCCTG-3' \\
\hline 11 & 5'-CAGGAGGCCCTGGTCTGCACTGTTT-3' & 5'-AGAACCACCGACCTGAACAGCC-3' \\
\hline 12 & $5^{\prime}$-AGACTTCAGGAGCTACAGAGA-3' & 5'-AGAGGAGGAACAAGAGAGGAA-3' \\
\hline 13 & 5'-CATCAGAGGCTGGCTGACAGCC-3' & 5'-AAGGCTTTAATTAAATTTGGG-3' \\
\hline
\end{tabular}

parental alleles represented $75 \%$ or more of the alleles present in the sample (14).

\section{Construction of TSHR and GNAS plasmid vectors}

The two new TSHR mutants were constructed using a pSVL-TSHR-WT (a gift from S Refetoff, Thyroid Study Unit, University of Chicago, IL, USA) as a backbone. Exon 10 DNA fragments of $1030 \mathrm{bp}$ were PCR amplified from thyroid tissue samples carrying those mutations. After gel purification (Qiaex II Gel Extraction Kit, Qiagen GmbH), fragments were subcloned into a pGEM-T TA cloning vector (Promega), transformed into Escherichia coli JM109 and verified by direct sequencing. Fragments of $567 \mathrm{bp}$ carrying the mutations were excised from a $p G E M-T$ TA cloning vector with Bsu 36I and BstEII restriction enzymes (New England Biolabs) and subcloned into the corresponding sites of the $p S V L-T S H R-W T$ vector.

For the new GNAS mutant, a plasmid vector was obtained by site-directed mutagenesis on a pSVK3GNAS-WT vector constructed as follows. Total RNA was obtained from a surgically excised normal thyroid tissue specimen and retrotranscribed using M-MLV reverse transcriptase (Invitrogen), $5 \mu \mathrm{M}$ random hexamers and $2 \mathrm{mM}$ deoxynucleotides (Ecogen, Barcelona, Spain) in a $20 \mu \mathrm{l}$ reaction volume. A GNAS cDNA fragment of 1158 bp was PCR amplified using 5'-GTCGACATGGGCTGCCTCGGGAACAG-3' as a forward primer and 5'-CAGCTGTTGGGGGTTCCCTTCTTCGA-3' as a reverse primer, both with a SalI restriction enzyme site (underlined sequence) located at the $5^{\prime}$ end. The fragment sequence showed that amplified cDNA corresponded to a GNAS transcript encoding a short form of Gs $\alpha$, which lacks 15 amino acids as a result of alternative splicing of exon 3, and has an extra serine residue due to an alternative splice acceptor site for exon 4 of the GNAS gene (15). After gel purification, the same fragment was inserted into a $p G E M-T$ TA cloning vector, transformed into E. coli JM109 and verified by direct sequencing. The GNAS insert was excised from the pGEM-T TA vector by SalI restriction enzyme (New England Biolabs) and cloned into a $p S V K 3$ vector (a gift from Michael A Levine, Children's Hospital Cleveland Clinic, OH, USA) previously linearized with SalI. Finally, the construct was sequenced to confirm the correct insertion of the GNAS coding transcript into the $p S V K 3$ vector. Site-directed mutagenesis (QuickChange II sitedirected mutagenesis kit, Stratagene, Madrid, Spain) was subsequently used to generate the new $p S V K 3$ GNAS mutant. Primer sequences and PCR conditions are available on request.

\section{Cell culture and transfection studies}

Constitutive activities of the new TSHR and adenylate cyclase-stimulating G- $\alpha$ protein mutants were investigated in co-transfection studies with a cAMP response element (CRE)-luciferase reporter plasmid (a gift from Dr Peter Syapin, Phamacology Department, TexasTech University). COS-7 cells (simian virus 40-transformed African green monkey kidney fibroblast) were grown at 
Table 2 Oligonucleotide sequences for PCR amplification of PRKAR1A exons $2-11$ and exons 2 and 3 of $R A S$ genes.

\begin{tabular}{|c|c|c|}
\hline Exon & Forward oligonucleotide & Reverse oligonucleotide \\
\hline \multicolumn{3}{|c|}{ PRKAR1A } \\
\hline 2 & 5'-TACAAGCATGTGTGTGTTTTTTTTC-3' & 5'-ТCACАATCАССТСАТСАТСТСС--3' \\
\hline 3 & 5'-ATTGGAACATGAGAGTGCCAGC-3' & 5'-GGATGAAGTTCCACCCTGTTTT-3' \\
\hline $4-5$ & 5'-GCAGGTTGCAAACGTGAAA-3' & 5'-CGCCTCCTCTCCCGTAAC-3' \\
\hline 6 & 5'-GCTTCTAАCTTTTTTTACССТСTTT-3' & 5'-AATCACTATTCTTATTGCTCGGAA-3' \\
\hline 7 & $5^{\prime}$-GGTTTGAGGGTTTTTAACATTTAAG-3' & 5'-TCACACTCTCAAACACCATGGT-3' \\
\hline 8 & $5^{\prime}$-ACAAGCTTTGACTTTCTGGTTTT- $3^{\prime}$ & $5^{\prime}$-TCCCAAGTCCATCCAATTCTA- $3^{\prime}$ \\
\hline 9 & 5'-CAGCACCAAATAATACAGAGCAG-3' & 5'-CCСTCTTAGAGCGTACAACTTTTT-3' \\
\hline 10 & 5'-TTGCATAGGATGTTTAAGGTGC-3' & $5^{\prime}$-TCAGGAGAAGACAAAATTATGGAA-3 \\
\hline 11 & 5'-TCATAGAAGTTAGCCTGTTACCCAT-3' & 5'-TGGCGCTGCAAGTAGGG-3' \\
\hline \multicolumn{3}{|c|}{ ש- } \\
\hline 2 & 5'-CTGAGGAGCGATGACGGAAT-3' & 5'-CTGGCACCTGGACGGC-3' \\
\hline 3 & 5'-GGGTCCCTGAGCCCTGTC-3' & 5'-CTGGCCCCACCTGTGC-3' \\
\hline \multicolumn{3}{|l|}{ KRAS } \\
\hline 2 & 5'-ATTATAAGGCCTGCTGAAAATGA-3' & 5'-GAAACCCAAGGTACATTTCAGATA-3' \\
\hline 3 & 5'-CTGTGTTTCTCCCTTCTCAGG-3' & 5'-GGCATTAGCAAAGACTCAAAAA-3' \\
\hline \multicolumn{3}{|r|}{ 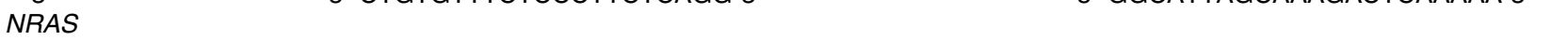 } \\
\hline 2 & 5'-GCTCGCCAATTAACCCTGATT-3' & 5'-GACAGGATCAGGTCAGCGG-3' \\
\hline 3 & 5'-AGCATTGCATTCCCTGTGGT-3' & 5'-TGTGGTAACCTCATTTCCCCA-3' \\
\hline
\end{tabular}

$100 \%$ confluence in $100 \times 20 \mathrm{~mm}$ polystyrene tissue culture dishes (Falcon, Franklin Lakes, NJ, USA) in DMEM (Sigma-Aldrich) containing 10\% foetal bovine serum (Sigma-Aldrich) and $50 \mu \mathrm{g} / \mathrm{l}$ gentamicin (SigmaAldrich), at $37^{\circ} \mathrm{C}$ in $100 \%$ humidity and $10 \% \mathrm{CO}_{2}$. For transient transfections, cells were transferred to 24-well culture plates ( $\sim 50000$ cells/well; Sarstedt, Barcelona, Spain) and grown in $500 \mu \mathrm{l}$ of the same medium until they reached $70-80 \%$ confluence. On the day of transfection, the medium was removed, cells were washed twice with PBS and to each well $500 \mu \mathrm{l}$ fresh medium was added, followed minutes later by Fugene 6.0 Reagent (Roche; $1.5 \mu \mathrm{l} /$ well), CRE-luciferase reporter plasmid (250 ng/well), together with $p S V L-T S H R$ wild-type $(250 \mathrm{ng} /$ well) or mutant expression $(250 \mathrm{ng} /$ well $)$ vector, or pSVL-TSHR wild-type $(50 \mathrm{ng} /$ well $)$ plus $50 \mathrm{ng} /$ well pSVK3-GNAS wild-type or mutant. After $48 \mathrm{~h}$ cells were harvested and luciferase activity was determined using a Luciferase Assay System (Promega) and luminometer (Junior LB 9509, Berthold, Germany). Each plasmid was transfected in quadruplicate and each experiment repeated at least twice.

\section{Statistical analysis}

Luciferase values (mean \pm s.D.) were compared by Student's $t$-test using SPSS, Chicago, IL, USA 12.0 for Windows (SPSS). $P<0.05$ was considered statistically significant.

\section{Results}

All patients had low or suppressed TSH (normal range: 0.41-4.94 mUI/l). Serum $\mathrm{FT}_{3}$ was elevated in $72 \%$ (normal range: $3.89-6.60 \mathrm{pmol} / \mathrm{l}$ ) and $\mathrm{FT}_{4}$ was elevated in 32\% (normal range: $10.94-21.75 \mathrm{pmol} / \mathrm{l}$ ) of patients. A solitary toxic adenoma was found in $47(61 \%)$ patients and a multinodular goitre with toxic adenoma(s) was found in 30 (39\%) patients. Average nodule diameter was $3.90 \mathrm{~cm}$ (range: $1.7-7.5 \mathrm{~cm}$ ). A papillary thyroid carcinoma was incidentally found in thyroid surgical specimens from eight $(10 \%)$ patients, with a diameter ranging from 0.1 to $1.5 \mathrm{~cm}$. None of the papillary thyroid carcinomas were found in hot nodules.

Mutations were found in $56(65.88 \%)$ samples (Table 3). Fifty-two samples $(61.2 \%)$ had mutations located in the TSHR gene and four samples $(4.71 \%)$ had mutations in the GNAS gene, but no samples were found to have mutations in either RAS or PKAR 1A genes. Nine patients each presented two toxic adenomas and, in two of those patients, there was a different TSHR mutation in each of the two nodules.

Although the number of women was higher than men, no differences were found in the mutation rate by gender $(68.9 \%$ women versus $62.5 \%$ men).

TSHR gene mutations were located in exon $9(2 / 56$, $3.57 \%$ total $)$ and exon 10 (50/56, 89.29\% total). Twentysix amino acids of the TSHR were affected by these mutations (Table 3). The majority of mutations were located in the sixth transmembrane segment and the third intracellular loop; serine ${ }^{281}$ was the only amino acid affected in the extracellular domain of the TSHR; each of the three extracellular loops of the TSHR were affected by one mutation (I486F, I568T and V656F); no mutations were found in the fourth transmembrane segment. As shown in Table 3, mutations were mostly transversions or transitions; only one mutation was caused by a triplet deletion $(\Delta 619)$ and the other was caused by substitution of two bases within a triplet (GCC $\rightarrow$ TTC A623F). The most frequent mutation was M453T (ten samples) located in the second transmembrane segment, followed by I568T (four samples) in the second extracellular loop of the TSHR. Mutations A623F and I635V had not been previously reported as naturally occurring mutations in the TSHR gene. 
Table 3 Thyroid-stimulating hormone receptor (TSHR) activating mutations in 85 toxic thyroid adenomas from Galicia, an iodinedeficient region with endemic goitre located in NW Spain.

\begin{tabular}{|c|c|c|c|c|}
\hline $\begin{array}{l}\text { Amino } \\
\text { acid }\end{array}$ & $\begin{array}{l}\text { Base } \\
\text { substitution }\end{array}$ & $\begin{array}{l}\text { Mutation } \\
\text { position }\end{array}$ & Pathology & $N$ \\
\hline $\mathrm{S} 281 \mathrm{~N}$ & $\mathrm{AGC} \rightarrow \mathrm{AAC}$ & ECD & MNG-TA & 1 \\
\hline S281T & $\mathrm{AGC} \rightarrow \mathrm{ACC}$ & ECD & MNG-TA & 1 \\
\hline S425I & $\mathrm{AGT} \rightarrow \mathrm{ATT}$ & 1st TMH & $\mathrm{TA}$ & 2 \\
\hline G431S & $\mathrm{GGC} \rightarrow \mathrm{AGC}$ & 1st TMH & TA & 1 \\
\hline M453T & ATG $\rightarrow$ ACG & 2nd TMH & MNG-TA (3)/TA (7) & 10 \\
\hline M463V & $\mathrm{ATG} \rightarrow \mathrm{GTG}$ & 2nd TMH & MNG-TA & \\
\hline I486F & ATC $\rightarrow$ TTC & 1st ECL & MNG-TA (1)/TA (2) & 3 \\
\hline L512R & $\mathrm{CTG} \rightarrow \mathrm{CGG}$ & 3rd TMH & MNG-TA (1)/TA (2) & 3 \\
\hline L512Q & $\mathrm{CTG} \rightarrow \mathrm{CAG}$ & 3rd TMH & TA & 1 \\
\hline I568T & $\mathrm{ATC} \rightarrow \mathrm{ACC}$ & 2nd ECL & MNG-TA (2)/TA (2) & 4 \\
\hline V597F & $\mathrm{GTC} \rightarrow \mathrm{TTC}$ & 5th TMH & TA & 1 \\
\hline V597L & $\mathrm{GTC} \rightarrow \mathrm{CTC}$ & 5th TMH & TA & 1 \\
\hline D619G & $\mathrm{GAT} \rightarrow \mathrm{GGT}$ & 3rd ICL & MNG-TA (2)/TA (1) & 3 \\
\hline$\Delta 619$ & GAT & 3rd ICL & TA & 1 \\
\hline A623V & $\mathrm{GCC} \rightarrow \mathrm{GTC}$ & 3rd ICL & TA & 1 \\
\hline A623I & $\mathrm{GCC} \rightarrow \mathrm{ATC}$ & 3rd ICL & TA & \\
\hline *A623F & $\mathrm{GCC} \rightarrow \mathrm{TTC}$ & 3rd ICL & $\mathrm{TA}$ & 1 \\
\hline L629F & TTG $\rightarrow$ TTC & 6th TMH & MNG-TA & 2 \\
\hline I630L & $\mathrm{ATC} \rightarrow \mathrm{CTC}$ & 6th TMH & TA & 1 \\
\hline F631L & TTC $\rightarrow$ CTC & 6th TMH & MNG-TA (1)/TA (2) & 3 \\
\hline T632I & $\mathrm{ACC} \rightarrow \mathrm{ATC}$ & 6th TMH & MNG-TA (1)/TA (2) & \\
\hline D633E & $\mathrm{GAC} \rightarrow \mathrm{GAA}$ & 6th $\mathrm{TMH}$ & MNG-TA (1)/TA (1) & \\
\hline D633Y & $\mathrm{GAC} \rightarrow \mathrm{TAC}$ & 6th $\mathrm{TMH}$ & MNG-TA & 1 \\
\hline D633H & $\mathrm{GAC} \rightarrow \mathrm{CAC}$ & 6th TMH & $\mathrm{TA}$ & 2 \\
\hline${ }^{*} \mid 635 \mathrm{~V}$ & ATA $\rightarrow$ GTA & 6th TMH & TA & \\
\hline V656F & $\mathrm{GTT} \rightarrow \mathrm{TTT}$ & 3rd ECL & TA & 1 \\
\hline
\end{tabular}

$N$, number of mutations; ECD, extracellular domain; $\mathrm{TMH}$, transmembrane domain; ECL, extracellular loop; ICL, intracellular loop; MNG-TA, toxic adenoma in a multinodular goitre; TA, toxic adenoma alone. Numbers in parenthesis indicate number of mutations. New mutations are marked by *.

Gs $\alpha$ protein mutations detected were: $\mathrm{R} 201 \mathrm{H}$ and a previously unreported L203P, both in exon 8 of GNAS, and Q227E and Q227H located in GNAS exon 9.

Three non-synonymous polymorphisms were found in the TSHR gene: amino acid 36 (aspartic acid $\rightarrow$ histidine, D36H, G/CAC (0.977 G/G homozygous, $0.023 \mathrm{G} / \mathrm{C}$ heterozygous)), amino acid 52 (proline $\rightarrow$ threonine, P52T, C/ACC (0.918 C/C homozygous, $0.082 \mathrm{C} / \mathrm{A}$ heterozygous)) and amino acid 727 (aspartic acid $\rightarrow$ glutamic acid, D727E, GAC/G $(0.919 \mathrm{C} / \mathrm{C}, 0.081 \mathrm{C} / \mathrm{G}))$. $\mathrm{D} 36 \mathrm{H}$ was associated once with $\mathrm{L} 512 \mathrm{R}$ and once with D619G TSHR gene mutations. P52T was associated once with T632I, once with D633E and once with D633H. D727E was associated once with G431S, M453T, V597F and F631L. Allele localization of polymorphisms and associated mutations was not determined.

Four synonymous polymorphisms were found in the GNAS gene, located at: isoleucine 131, ATT/C (0.400 T/C heterozygous, $0.300 \mathrm{~T} / \mathrm{T}$ homozygous, $0.300 \mathrm{C} / \mathrm{C}$ homozygous), proline $144, \mathrm{CCC} / \mathrm{T}$ (0.940 $\mathrm{C} / \mathrm{C}$ homozygous, $0.060 \mathrm{C} / \mathrm{T}$ heterozygous), glycine 185 , ATC/T $(0.940 \mathrm{C} / \mathrm{C}$ homozygous, $0.060 \mathrm{C} / \mathrm{T}$ heterozygous), asparagine 371 (0.940 C/C homozygous, 0.060 $\mathrm{C} / \mathrm{T}$ heterozygous). A non-synonymous polymorphism was also observed at amino acid 322 (glutamic acid $\rightarrow$ aspartic acid, E322D, GAG/T, (0.940 G/G homozygous, $0.060 \mathrm{G} / \mathrm{T}$ heterozygous)).

One synonymous polymorphism was found in the PRKAR1A gene, at alanine 29, GCG/A (0.830 G/G homozygous, $0.170 \mathrm{G} / \mathrm{A}$ heterozygous).

The clonality assay was performed on 23 informative samples. Of these samples, $6(26 \%)$ were found to be monoclonal and 17 samples $(74 \%)$ polyclonal. Two monoclonal $(2 / 6,33.3 \%)$ and ten polyclonal samples $(10 / 17,58.8 \%)$ had mutations in either the TSHR gene or GNAS gene.

The three new identified mutations, TSHR A623F and $\mathrm{I} 635 \mathrm{~V}$, and Gs $\alpha$ protein L203P showed statistically significant higher basal constitutive cAMP activity than their counterpart wild types (Fig. 1).

\section{Discussion}

Galicia is an iodine-deficient region located in NW Spain with a high prevalence of toxic multinodular goitre. Activating mutations in the TSHR (4) and GNAS (5) genes are frequently found in toxic non-autoimmune multinodular goitre, accounting for nearly $80 \%$ of cases
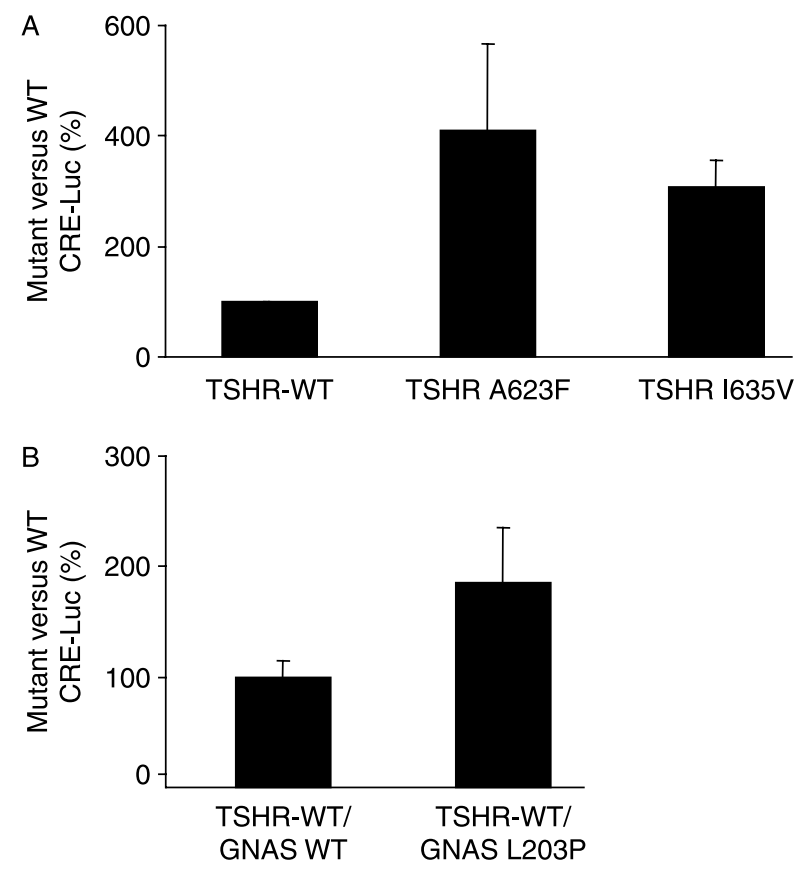

Figure 1 Basal constitutive cAMP activity of TSH receptor $(A)$ and Gs $\alpha$ protein (B) previously unreported mutants vs wild-types. COS7 cells were co-transfected with $250 \mathrm{ng} /$ well of either wild-type or mutant plasmid and, either $250 \mathrm{ng} /$ well of a cAMP response element (CRE)-luciferase plasmid for TSH receptor experiments, or $50 \mathrm{ng} /$ well of TSH receptor wild-type and $50 \mathrm{ng} /$ well of GNAS wildtype or mutant. After $48 \mathrm{hr}$ CRE-luciferase was measured. Values from wild-types are shown as $100 \%$. TSHR and GNAS mutants showed statistically-significant higher basal luciferase values than wild-types, indicating a higher constitutive cAMP activity for the mutants. 
in some European series (16-24). In agreement with previous studies, a high prevalence of mutation in the TSHR gene was found in our TA series from Galician patients. All mutated TSHR showed higher basal cAMP levels than the wild-type TSHR (see http://gris.ulb.ac. be, http://innere.uniklinikum-leipzig.de/tsh/).

Additionally, three non-synonymous polymorphisms were found in the TSHR gene. D36H and P52T, in the extracellular portion of the TSHR, have been previously reported in European patients with Graves' disease and in healthy controls (25). Neither D36H nor P52T have been shown to have any differences either in TSHR binding $(26,27)$ or basal cAMP production level $(28)$, compared with the TSHR wild-type. The third polymorphism that we found, D727E, showed a frequency close to the one reported in German patients (28). The D727E polymorphism is located within the carboxy terminal tail of the TSHR and in one study has been associated with non-autoimmune toxic multinodular goitre (29). A subsequent study, however, provided evidence against such an association (28). Functional studies have shown no differences in basal and TSHstimulated CRE-luciferase activities between D727E and wild-type TSHR $(20,30,31)$. Interestingly, in vitro studies performed with a double mutant A593N/D727E showed higher constitutive activity than D727E, although the double mutant had 2.3-fold lower constitutive activity than the A593N mutant alone (31). This finding suggests that constitutive activities of mutant TSHR could be modified by the presence in the same TSHR gene allele of D727E or other nonsynonymous polymorphisms.

Two previously unreported mutations were located in the TSHR, A623F and I635V. Alanine ${ }^{623}$ is located in the third cytoplasmic loop, which plays a key role in the interaction of the TSHR with G-proteins. Mutations by isoleucine (4), valine (17) and serine (32) have previously been reported as naturally occurring activating mutations in TA. Substituting alanine ${ }^{623}$ for glutamic acid or lysine results in loss of TSH-stimulated inositol phosphate formation but does not increase basal cAMP accumulation (33). In the present study, the new mutation A623F showed an increased basal cAMP-mediated CRE-luciferase activity compared with the wild-type TSHR, indicating that substitution of alanine ${ }^{623}$ for phenylalanine is an activating mutation. Phenylalanine is a highly hydrophobic amino acid, suggesting that activating mutations

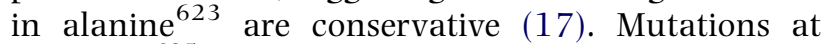
isoleucine $^{635}$ had not previously been reported for the TSHR. Isoleucine ${ }^{635}$ is located in the sixth transmembrane domain, and it is probable that a substitution of isoleucine for valine, both that are also highly hydrophobic amino acids, modifies the relative positions of the helices thus causing an increase in constitutive activity of the receptor.

The fact that in 85 samples of TA only two new TSHR gene mutations were found suggests that most naturally occurring activating mutations in the TSHR have now been described (see http:/gris.ulb.ac.be, http://innere.uniklinikum-leipzig.de/tsh/). There are, however, also several artificially created activating mutations located in amino acid residues where naturally occurring mutations have not been found to date (http://gris.ulb.ac.be). This raises the question of why naturally occurring activating mutations do not occur in some TSHR amino acids that have the capacity to constitutively activate the receptor.

The most frequent mutations in our series were $\mathrm{C} \rightarrow \mathrm{T}$ and $\mathrm{T} \rightarrow \mathrm{C}$ transitions and $\mathrm{G} \rightarrow \mathrm{T}$ transversions. $\mathrm{CpG}$ dinucleotides undergo TG transversions at high frequency (34). Since methylated CpG islands are prone to mutation due to deamination of 5-methylcytosine (35), we performed an in silico analysis (Methyl Primer Express Software 1.0, Applied Biosystem) of the TSHR gene coding sequence that showed a hypothetical 760 bp CpG island inside exon 10. Of the mutations we studied, only the T632I mutation was located in this hypothetical methylated $\mathrm{CpG}$ island, suggesting that deamination of 5-methylcytosine is not a common mutagenic mechanism in TA (36). Replication slippage in quasi-palindromic DNA sequences causes frameshift and base-substitution mutations (37). A computational analysis of the TSHR gene using Mfold version 3.2 (http://mfold.bioinfo.rpi.edu) indicates that imperfect DNA complementarity is not a cause for the high frequency of M453T mutation. Oxidative damage caused by an increase in $\mathrm{H}_{2} \mathrm{O}_{2}$ generation in thyroid glands under conditions of iodine and selenium deficiency could be a major cause for the high mutational rate at identified codons (38).

Activating GNAS mutations were found at much lower frequency than TSHR mutations, as shown by others $(19,23,39,40)$. Previous to our study, however, activating GNAS mutations causing TA had only been found at $\mathrm{Gs} \alpha$ residues arginine $\mathrm{e}^{201}$ or glutamine $\mathrm{g}^{227}$, which also cause growth hormone-secreting adenoma, corticotroph adenoma, non-functional pituitary adenoma, adrenal adenoma or macronodular adrenal hyperplasia, McCune-Albright syndrome and fibrous dysplasia of the bone (15). Gs $\alpha$ arginine ${ }^{201}$ is the site at which cholera toxin catalyses ADP-ribosylation inhibiting Gs $\alpha$ subunit intrinsic GTPase activity. As a result of reduced GTPase activity, Gs $\alpha$ remains in its active GTPbound form causing an unregulated activation of adenylyl cyclase (41). Replacement of arginine ${ }^{201}$ by histidine decreases intrinsic GTPase activity and leads to activation of adenylyl cyclase (41). Gs $\alpha$ residue glutamine ${ }^{227}$ belongs to the protein guanine nucleotide binding domain (42). Replacement of glutamine ${ }^{227}$ by glutamic acid or histidine decreases GTP hydrolysis by slowing the switch mechanism that mediates the conformational transition between the GTP- and GDPbound forms, leading to activation of adenylyl cyclase (42). No activating GNAS mutations have previously been reported in Gs $\alpha$ residue leucine ${ }^{203}$, located near $\operatorname{arginine}^{201}$. A naturally occurring substitution of 
leucine ${ }^{203}$ by proline was found in one TA from our series and in vitro analysis showed an increase in constitutive CRE-luciferase activity in cells co-transfected with $p S V L-T S H R$ wild-type plus pSVK3-GNAS proline ${ }^{203}$, suggesting that the mutant caused an increase in intracellular cAMP levels. These results indicate that, like the Gs $\alpha$ residue arginine ${ }^{201}$, the Gs $\alpha$ amino acid leucine ${ }^{203}$ participates in the GTPase turnoff reaction.

PKA plays a central role in the cAMP signalling pathway. In a previous study of a large series of hyperactive thyroid nodules, no mutations were found in the PKA catalytic subunit (43). Correspondingly, in the present TA series, no mutations in the PRKAR1A gene coding region were found in toxic adenomas. Together, these findings suggest that mutations in PKA are not involved in the development of toxic TAs.

In rat thyroid cells, TSH stimulates cell proliferation via a cAMP-mediated pathway that requires activation of RAS mediated by a mechanism independent of PKA activity (44). Ras mutations are observed in both benign and malignant thyroid neoplasias $(45,46)$ and have also been reported in TA (11). In the present study of TA, no mutations were found in codons 12,13 or 61 of the Ras oncogene, suggesting that if RAS is involved in toxic TA its involvement is minimal.

In the present study, the number of polyclonally derived TAs exceeded those that were monoclonal, with polyclonal tumours exhibiting a higher percentage of mutations. Previous studies had shown a monoclonal origin for nearly all thyroid toxic nodules bearing activating mutations in either the TSHR or Gs $\alpha$ protein, as well as for half the number of nodules in which mutations were not found (47). Clonal analysis is affected by the cut-off criterion for clonality, by contamination of samples with connective and/or vascular tissue and by the thyroid patch, a cluster of thyroid progenitor cells with the same pattern of $\mathrm{X}$ chromosome inactivation (2). A low cut-off value will increase the number of monoclonal samples thereby decreasing specificity. In the present study, lowering the cut-off value from 3 to 2 (47) would increase the number of monoclonal samples from $6(26 \%)$ to 14 $(61 \%)$ and would increase the number of mutations in the monoclonal samples from 33.3 to $50 \%$. However, even with a cut-off value of 2 , our percentage of polyclonal samples is high. Since a large patch size would bias clonality assays towards monoclonality, the high number of polyclonal nodules detected in our study seems to indicate that DNA samples analyzed were probably a compound mixture of thyrocytes, connective and/or vascular tissue.

Denaturing gradient gel electrophoresis (DGGE) is more sensitive than direct sequencing in detecting TSHR gene mutations (48) and DGGE could therefore have been used to increase the likelihood of detecting mutations in thyroid TA samples containing high amounts of connective and/or vascular tissue. However, direct sequencing can detect amounts of mutated DNA between 12 and $50 \%$ of total DNA (48), and it should therefore be sufficiently sensitive to detect mutations in those samples identified as monoclonal using a high cut-off criterion for clonality. Monoclonal TAs without mutations in TSHR, GNAS, PRKAR1A or RAS genes should have mutations in other as yet unidentified genes.

Although not an aim of the present study, a papillary thyroid carcinoma was incidentally found in $10 \%$ of the thyroid surgical specimens studied. The reported incidental finding of thyroid carcinoma among patients undergoing surgery for benign thyroid disease ranges from 3 to $16 \%$ (49), including toxic uni- or multinodular goitre (50). Our results are in agreement with those from surgical patients with hyperthyroidism due to toxic multinodular goitre or toxic adenoma where a prevalence of thyroid carcinoma of $7-8 \%$ has been reported (51).

In conclusion, nearly $66 \%$ of toxic TAs from a large series of patients in Galicia, an iodine-deficient region located in NW Spain, have activating mutations in either the TSHR or GNAS gene. Based on our study, PRKAR1A gene and RAS genes do not appear to be involved in TA aetiology in that community. Only 2 out of 52 activating TSHR gene mutations were previously unreported, suggesting that most TSHR mutations have been already reported. A naturally occurring new activating mutation in GNAS, L203P, was also found in one TA, showing that residue leucine ${ }^{203}$ is important in the regulation of Gs $\alpha$-subunit intrinsic GTPase activity. The underlying genetic $\operatorname{defect}(\mathrm{s})$ remain(s) unknown in one-third of TAs from Galicia.

\section{Declaration of interest}

The authors declare that there is no conflict of interest that could be perceived as prejudicing the impartiality of the research reported.

\section{Funding}

This study was supported by the following grants: Fondo de Investigaciones Sanitarias FIS PI030401 (J L-A), Ministerio de Educación SAF2006-02542 (J L-A), Xunta de Galicia PGIDIT04PXIC20801PN (J L-A), PGIDIT06PXIB 208360PR (J L-A) and Instituto de Salud Carlos III PI060209 (J C-T).

\section{References}

1 Studer H \& Ramelli F. Simple goiter and its variants: euthyroid and hyperthyroid multinodular goiters. Endocrine Reviews 19823 40-61.

2 Krohn K, Führer D, Bayer Y, Eszlinger M, Brauer V, Neumann S \& Paschke R. Molecular pathogenesis of euthyroid and toxic multinodular goiter. Endocrine Reviews 200526 504-524. 
3 Vanderpump MPJ \& Tunbridge WMG. The epidemiology of thyroid diseases. In Werner and Ingbar's the Thyroid. A Fundamental and Clinical Text, edn 8, ch 25, pp 467-473. Eds LE Braverman \& RD Utiger. Philadelphia: Lippincott Williams \& Wilkins, 2000.

4 Parma J, Duprez L, Van Sande J, Cochaux P, Gervy C, Mockel J, Dumont JE \& Vassart G. Somatic mutations in the thyrotropin receptor gene cause hyperfunctioning thyroid adenomas. Nature $2003365649-651$.

5 O'Sullivan C, Barton CM, Staddon SL, Brown CL \& Lemoine NR. Activating point mutations of the gsp oncogene in human thyroid adenomas. Molecular Carcinogenesis 19914 345-349.

6 Vassar G \& Dumont JE. The thyrotropin receptor and the regulation of thyrocyte function and growth. Endocrine Reviews 199213 596-611.

7 Parma J, Van Sande J, Swillens S, Tonacchera M, Dumont J \& Vassart G. Somatic mutations causing constitutive activity of the thyrotropin receptor are the major cause of hyperfunctioning thyroid adenomas: identification of additional mutations activating both the cyclic adenosine $3^{\prime}, 5^{\prime}$-monophosphate and inositol phosphate-Ca ${ }^{2+}$ cascades. Molecular Endocrinology 19959 $725-733$.

8 Rivas M \& Santisteban P. TSH-activated signaling pathways in thyroid tumorogenesis. Molecular and Cellular Endocrinology 2003 213 31-45.

9 Stratakis CA, Courcoutsakis NA, Abati A, Filie A, Doppman JL, Carney JA \& Shawker T. Thyroid gland abnormalities in patients with the syndrome of spotty skin pigmentation, myxomas, endocrine overactivity, and schwannomas (Carney complex). Journal of Clinical Endocrinology and Metabolism $1997 \mathbf{8 2}$ 2037-2043.

10 Bos JL. Ras oncogenes in human cancer: a review. Cancer Research $1989494682-4689$.

11 Russo D, Arturi F, Wicker R, Chazenbalk GD, Schlumberger M, DuVillard JA, Caillou B, Monier R, Rapoport B, Filetti S \& Suarez HG. Genetic alterations in thyroid hyperfunctioning adenomas. Journal of Clinical Endocrinology and Metabolism 1995 80 1347-1351.

12 Rego-Iraeta A, Pérez-Fdez R, Cadarso-Suárez C, Tomé M, FdezMariño A, Mato JA, Botana M \& Solache I. Iodine nutrition in the adult population of galicia (Spain). Thyroid 200717 161-167.

13 Allen RC, Zoghbi HY, Moseley AB, Rosenblatt HM \& Belmont JW. Methylation of HpaII and HhaI sites near the polymorphic CAG repeat in the human androgen-receptor gene correlates with $\mathrm{X}$ chromosome inactivation. American Journal of Human Genetics 199251 1229-1239.

14 Kopp P, Jaggi R, Tobler A, Borisch B, Oestreicher M, Sabacan L, Jameson JL \& Fey MF. Clonal X-inactivation analysis of human tumours using the human androgen receptor gene (HUMARA) polymorphism: a non-radioactive and semiquantitative strategy applicable to fresh and archival tissue. Molecular and Cellular Probes $199711217-228$.

15 Weinstein LS, Yu S, Warner DR \& Liu J. Endocrine manifestations of stimulatory $\mathrm{G}$ protein $\alpha$-subunit mutations and the role of genomic imprinting. Endocrine Reviews 200122 675-705.

16 Porcellini A, Ciullo I, Laviola L, Amabile A, Fenzi G \& Avvedimento V. Novel mutations of thyrotropin receptor gene in thyroid hyperfunctioning adenomas. Journal of Clinical Endocrinology and Metabolism 199479 657-661.

17 Paschke R, Tonacchera M, Van Sande J, Parma J \& Vassart G. Identification and functional characterization of two new somatic mutations causing constitutive activation of the thyrotropin receptor in hyperfunctioning autonomous adenomas of the thyroid. Journal of Clinical Endocrinology and Metabolism 199479 1785-1789.

18 Russo D, Arturi F, Suarez HG, Schlumberger M, Du Villard JA, Crocetti U \& Filetti S. Thyrotropin receptor gene alterations in thyroid hyperfunctioning adenomas. Journal of Clinical Endocrinology and Metabolism 19968 1548-1551.

19 Parma J, Duprez L, Van Sande J, Hermans J, Rocmans P, Van Vliet G, Costagliola S, Rodien P, Dumont JE \& Vassart G. Diversity and prevalence of somatic mutations in the thyrotropin receptor and Gs alpha genes as a cause of toxic thyroid adenomas. Journal of Clinical Endocrinology and Metabolism 199782 2695-2701.

20 Fuhrer D, Holzapfel HP, Wonerow P, Scherbaum WA \& Paschke R. Somatic mutations in the thyrotropin receptor gene and not in the Gs alpha protein gene in 31 toxic thyroid nodules. Journal of Clinical Endocrinology and Metabolism 199782 3885-3891.

21 Holzapfel HP, Führer D, Wonerow P, Weinland G, Scherbaum WA \& Paschke R. Identification of constitutively activating somatic thyrotropin receptor mutations in a subset of toxic multinodular goiters. Journal of Clinical Endocrinology and Metabolism 199782 4229-4233.

22 Tonacchera M, Chiovato L, Pinchera A, Agretti P, Fiore E, Cetani F, Rocchi R, Viacava P, Miccoli P \& Vitti P. Hyperfunctioning thyroid nodules in toxic multinodular goiter share activating thyrotropin receptor mutations with solitary toxic adenoma. Journal of Clinical Endocrinology and Metabolism $1998 \mathbf{8 3} 492-498$.

23 Georgopoulos NA, Sykiotis GP, Sgourou A, Papachatzopoulou A, Markou KB, Kyriazopoulou V, Papavassiliou AG \& Vagenakis AG. Autonomously functioning thyroid nodules in a former iodinedeficient area commonly harbor gain-of-function mutations in the thyrotropin signaling pathway. European Journal of Endocrinology $2003149287-292$.

24 Gozu HI, Bircan R, Krohn K, Müller S, Vural S, Gezen C, Sargin H, Yavuzer D, Sargin M, Cirakoglu B \& Paschke R. Similar prevalence of somatic TSH receptor and Gsalpha mutations in toxic thyroid nodules in geographical regions with different iodine supply in Turkey. European Journal of Endocrinology 2006155 535-545.

25 Simanainen J, Kinch A, Westermark K, Winsa B, Bengtsson M, Schuppert F, Westermark B \& Heldin NE. Analysis of mutations in exon 1 of the human thyrotropin receptor gene: high frequency of the D36H and P52T polymorphic variants. Thyroid 1999 9 7-11.

26 Gustavsson B, Eklöf C, Westermark K, Westermark B \& Heldin NE. Functional analysis of a variant of the thyrotropin receptor gene in a family with Graves' disease. Molecular and Cellular Endocrinology $1995111167-173$.

27 Loos U, Hagner S, Bohr UR, Bogatkewitsch GS, Jakobs KH \& Van Koppen CJ. Enhanced cAMP accumulation by the human thyrotropin receptor variant with the Pro52Thr substitution in the extracellular domain. European Journal of Biochemistry 1995 232 62-65.

28 Muhlberg T, Herrmann K, Joba W, Kirchberger M, Heberling H-J \& Heufelder AE. Lack of association of nonautoimmune hyperfunctioning thyroid disorders and a germline polymorphism of codon 727 of the human thyrotropin receptor in a European Caucasian Population. Journal of Clinical Endocrinology and Metabolism 2000 85 2640-2643.

29 Gabriel EM, Bergert ER, Grant CS, van Heerden JA, Thompson GB \& Morris JC. Germline polymorphism of codon 727 of human thyroid-stimulating hormone receptor is associated with toxic multinodular goiter. Journal of Clinical Endocrinology and Metabolism 199984 3328-3335.

30 Nogueira CR, Kopp P, Arseven OK, Santos CL, Jameson JL \& Medeiros-Neto G. Thyrotropin receptor mutations in hyperfunctioning thyroid adenomas from Brazil. Thyroid $1999 \mathbf{1 1}$ 1063-1068.

31 Sykiotis GP, Neumann S, Georgopoulos NA, Sgourou A, Papachatzopoulou A, Markou KB, Kyriazopoulou V, Paschke R, Vagenakis AG \& Papavassiliou AG. Functional significance of the thyrotropin receptor germline polymorphism D727E. Biochemical and Biophysical Research Communications 2003301 1051-1056.

32 Russo D, Arturi F, Schlumberger M, Caillou B, Monier R, Filetti S \& Suárez HG. Activating mutations of the TSH receptor in differentiated thyroid carcinomas. Oncogene 199511 1907-1911.

33 Kosugi S, Okajima F, Ban T, Hidaka A, Shenker A \& Kohn LD. Mutation of alanine 623 in the third cytoplasmic loop of the rat thyrotropin (TSH) receptor results in a loss in the phosphoinositide but not cAMP signal induced by TSH and receptor autoantibodies. Journal of Biological Chemistry 1992267 24153-24156. 
34 Krawczak M, Ball EV \& Cooper DN. Neighboring-nucleotide effects on the rates of germ lines single-base-pair substitution in human genes. American Journal of Human Genetics 199863 474-488.

35 Shen JC, Rideout WM III \& Jones PA. The rate of hydrolytic deamination of 5-methylcytosine in double-stranded DNA. Nucleic Acids Research 199422 972-976.

36 Farid NR, Kascur V \& Balazs C. The human thyrotropin receptor is highly mutable: a review of gain-of-function mutations. European Journal of Endocrinology 2000143 25-30.

37 Lado-Abeal J, Dumitrescu AM, Liao XH, Cohen RN, Pohlenz J, Weiss RE, Lebrethon MC, Verloes A \& Refetoff S. A de novo mutation in an already mutant nucleotide of the thyroid hormone receptor beta gene perpetuates resistance to thyroid hormone. Journal of Clinical Endocrinology and Metabolism 200590 1760-1767.

38 Krohn K, Maier J \& Paschke R. Mechanisms of disease: hydrogen peroxide, DNA damage and mutagenesis in the development of thyroid tumors. Nature Clinical Practice. Endocrinology \& Metabolism 20073 713-720.

39 Trülzsch B, Krohn K, Wonerow P, Chey S, Holzapfel HP, Ackermann F, Führer D \& Paschke R. Detection of thyroidstimulating hormone receptor and Gsalpha mutations: in 75 toxic thyroid nodules by denaturing gradient gel electrophoresis. Journal of Molecular Medicine 200178 684-691.

40 Vanvooren V, Uchino S, Duprez L, Costa MJ, Vandekerckhove J, Parma J, Vassart G, Dumont JE, Van Sande J \& Noguchi S. Oncogenic mutations in the thyrotropin receptor of autonomously functioning thyroid nodules in the Japanese population. European Journal of Endocrinology 2002147 287-291.

41 Schwindinger WF, Francomano CA \& Levine MA. Identification of a mutation in the gene encoding the alpha subunit of the stimulatory $G$ protein of adenylyl cyclase in McCune-Albright syndrome. PNAS $1992 \mathbf{8 9} 5152-5156$.

42 Masters SB, Miller RT, Chi MH, Chang FH, Beiderman B, Lopez NG \& Bourne HR. Mutations in the GTP-binding site of GS alpha alter stimulation of adenylyl cyclase. Journal of Biological Chemistry $198926415467-15474$.
43 Gozu H, Avsar M, Bircan R, Sahin S, Deyneli O, Cirakoglu B \& Akalin S. Mutations in the thyrotropin receptor signal transduction pathway in the hyperfunctioning thyroid nodules from multinodular goiters: a study in the Turkish population. Endocrine Journal $2005 \mathbf{5 2} 577-585$.

44 Tsygankova OM, Kupperman E, Wen W \& Meinkoth JL. Cyclic AMP activates Ras. Oncogene 200019 3609-3615.

45 Esapa CT, Johnson SJ, Kendall-Taylor P, Lennard TW \& Harris PE. Prevalence of Ras mutations in thyroid neoplasia. Clinical Endocrinology $1999 \mathbf{5 0} 529-535$.

46 Kondo T, Ezzat $S$ \& Asa SL. Pathogenetic mechanisms in thyroid-follicular-cell neoplasia. Nature Reviews. Cancer 20066 292-306.

47 Krohn K, Führer D, Holzapfel HP \& Paschke R. Clonal origin of toxic thyroid nodules with constitutively activating thyrotropin receptor mutations. Journal of Clinical Endocrinology and Metabolism 199883 130-134.

48 Trülzsch B, Krohn K, Wonerow P \& Paschke R. DGGE is more sensitive for the detection of somatic point mutations than direct sequencing. BioTechniques 199927 266-268.

49 Roti E, Rossi R, Trasforini G, Bertelli F, Ambrosio MR, Busutti L, Pearce EN, Braverman LE \& Degli Uberti EC. Clinical and histological characteristics of papillary thyroid microcarcinoma: results of a retrospective study in 243 patients. Journal of Clinical Endocrinology and Metabolism $2006912171-2178$.

50 Miccoli P, Minuto MN, Galleri D, D'Agostino J, Basolo F, Antonangeli L, Aghini-Lombardi F \& Berti P. Incidental thyroid carcinoma in a large series of consecutive patients operated on for benign thyroid disease. Australian and New Zealand Journal of Surgery 200676 123-126.

51 Cakir M, Arici C, Alakus H, Altunbas H, Balci MK \& Karayalcin U. Incidental thyroid carcinoma in thyrotoxic patients treated by surgery. Hormone Research 2007 67 96-99.

Received 6 July 2008

Accepted 5 August 2008 